\title{
Ghrelin regulates proliferation and differentiation of osteoblastic cells
}

\author{
Giuseppina Maccarinelli, Valeria Sibilia ${ }^{1}$, Antonio Torsello ${ }^{2}$, \\ Francesca Raimondo², Marina Pitto ${ }^{2}$, Andrea Giustina ${ }^{3}$, \\ Carmela Netti ${ }^{1}$ and Daniela Cocchi
}

\author{
Department of Biomedical Sciences and Biotechnology, University of Brescia, Brescia, Italy \\ ${ }^{1}$ Department of Pharmacology, University of Milano, Milano, Italy \\ ${ }^{2}$ Department of Experimental and Environmental Medicine and Biotechnologies, University of Milano-Bicocca, Monza, Italy \\ ${ }^{3}$ Department of Medical and Surgical Sciences, University of Brescia, Brescia, Italy \\ (Requests for offprints should be addressed to D Cocchi, Department of Biomedical Sciences and Biotechnology, University of Brescia, Viale Europa 11, \\ 25123 Brescia, Italy; Email: cocchi@med.unibs.it)
}

\begin{abstract}
It has previously been reported that growth hormone secretagogues (GHS) may have a role in the regulation of bone metabolism in animals and humans. In this study we evaluated the effect of ghrelin, the endogenous ligand of GHS receptors, on the proliferation rate and on osteoblast activity in primary cultures of rat calvaria osteoblasts. In the same experiments, we compared the effects of ghrelin with those of hexarelin (HEXA) and EP-40737, two synthetic GHS with different characteristics. Both ghrelin and HEXA $\left(10^{-11}-10^{-8} \mathrm{M}\right)$ significantly stimulated osteoblast proliferation at low concentrations $\left(10^{-10} \mathrm{M}\right)$. Surprisingly, EP-40737 demonstrated an antiproliferative effect at $10^{-9}-10^{-8} \mathrm{M}$, whereas lower concentrations
\end{abstract}

had no effect on cell proliferation. Ghrelin and HEXA significantly increased alkaline phosphatase (ALP) and osteocalcin (OC) production. At variance with these peptides, EP-40737 did not significantly stimulate ALP and OC. The mRNA for GHS-R1a receptors and the corresponding protein were detected in calvarial osteoblasts by RT-PCR and Western blot respectively, indicating that ghrelin and GHS may bind and activate this specific receptor. We conclude that endogenous ghrelin and synthetic GHS modulate proliferation and differentiation of rat osteoblasts, probably by acting on their specific receptor.

Journal of Endocrinology (2005) 184, 249-256

\section{Introduction}

Growth hormone secretagogues (GHS) are synthetic compounds that elicit growth hormone $(\mathrm{GH})$ release both in vivo and in vitro (Locatelli \& Torsello 1997) through interaction with specific GHS receptors (GHS-R) (Petersenn 2002). Two GHS-R mRNA isoforms produced by alternative mRNA processing have been identified so far: the full-length 1a receptor and the truncated GHS-R1b type (Petersenn 2002). The GHS-R1a is the functional form of the receptor that mediates the neuroendocrine effects of GHS, whereas the functional significance, if any, of GHS-R1b remains to be elucidated. Recently, an endogenous ligand for GHS-R1a was cloned from rat and human stomach, and was named ghrelin. Ghrelin was shown to be a 28 amino acid peptide bearing the unique acylation on the $\mathrm{Ser}^{3}$ residue (Kojima et al. 1999, 2001). Ghrelin, as well as many GHS, also participates in the regulation of energy homeostasis (Inui 2001), cardiovascular (Bodart et al. 1999, Locatelli et al. 1999) and gastric functions (Sibilia et al. 2002). However, the widespread expression of the genes encoding ghrelin and its cognate receptor in a variety of tissues including adrenals, prostate, thymus, hypothalamus, hippocampus and bone (Komatsu et al. 2000, Broglio et al. 2002, Guanapavan et al. 2002) strongly supports a potential for multiple biological activities of ghrelin (van der Lely et al. 2004). The possibility that ghrelin could be involved in the control of bone metabolism is also strengthened by the observation that gastrectomy induces osteopaenia (Bussabergher et al. 1938, Ivy 1940, Rümenappf et al. 1997) and that the acid-producing (oxyntic) mucosa (where ghrelin is synthesized) is important for bone metabolism (Lehto-Axtelius et al. 1998). Providing support for this hypothesis, we have previously reported that hexarelin (HEXA), a synthetic GHS, was capable of counteracting bone loss in male gonadectomized rats (Sibilia et al. 1999). Similarly, oral administration of GHS compounds was reported to increase bone turnover in humans (Svensson et al. 2001). A very interesting possibility is that the 
protective effect of HEXA on bone could be due not solely to its GH-releasing activity but also to direct effects on bone cell activities.

In this study we tested whether the latter hypothesis is true by evaluating the effect of HEXA and EP-40737 (another GHS that stimulates GH secretion but not food intake in rats) on the proliferation rate and on osteoblast activity in primary cultures of rat calvaria cells. In the same experiments we compared the effect of HEXA and EP-40737 with those of ghrelin, the endogenous ligand of GHS-R1a. Furthermore, to assess the specificity of action of the compounds examined, the expression of GHS-R1a in our osteoblast cell line was determined by RT-PCR and Western blot.

\section{Materials and Methods}

\section{Primary osteoblast cultures}

All experimental protocols met the Italian Guidelines for the Use of Laboratory Animals which conform with the European Union Directive of November 1986 (86/609/ EEC). The primary osteoblastic cells were obtained from rat calvariae explanted from E 21 fetuses as previously described by Bellows and coworkers (1987) with modifications. Briefly, calvaria were finely minced and incubated three times with $5 \mathrm{ml}$ of an enzyme mixture containing $1 \mathrm{mg} / \mathrm{ml}$ collagenase type IV and $0 \cdot 25 \%$ trypsin (1:250) (Sigma-Aldrich, Italy). Dispersed cells were collected after $20 \mathrm{~min}$ (population 1), $30 \mathrm{~min}$ (population 2) and $60 \mathrm{~min}$ (population 3) of incubation. An equivalent volume of fresh enzyme was added after each cell separation. Immediately after harvesting, an equal volume of Dulbecco's modified Eagle's medium (DMEM, Gibco, UK) containing $10 \%$ of fetal bovine serum (FCS, Sigma-Aldrich) was added to the cell suspension to block the enzymatic activity. The cells were then pelleted by centrifugation, resuspended in DMEM and the three cell populations were pooled. The cells were then cultured in DMEM containing $10 \%$ FCS, $1 \%$ L-glutamine, $100 \mathrm{mg} / \mathrm{ml}$ penicillin and $10 \mathrm{IU}$ streptomycin. The cells in culture were confirmed to be osteoblasts both by morphology and alkaline phosphatase (ALP) expression (see below). When confluence was reached, the medium was also supplemented with $50 \mu \mathrm{g} / \mathrm{ml}$ ascorbic acid and $3 \mathrm{mM}$ $\beta$-glycerophosphate ( Sigma-Aldrich) to trigger osteoblast differentiation.

The experiments were performed on cells at passage 6 when maximal ALP expression was found. The day before the experiment, the culture medium was removed and cells were maintained in DMEM without FCS for $24 \mathrm{~h}$. Cells were then incubated with fresh DMEM containing HEXA $\left(10^{-11}-10^{-9} \mathrm{M}\right)$, ghrelin $\left(10^{-11}-10^{-9} \mathrm{M}\right)$, EP-40737 $\left(10^{-11}-10^{-9} \mathrm{M}\right)$, vitamin D (Vit D) $\left(10^{-9} \mathrm{M}\right)$ or FCS $(10 \%)$ for $24-48 \mathrm{~h}$.

\section{$P^{3}$ H]Thymidine incorporation assay}

The cells were plated at a density of $1.3 \times 10^{4} \mathrm{cells} / \mathrm{cm}^{2}$ in 24-well plates. At confluence the cells were incubated for $24 \mathrm{~h}$ in DMEM without FCS. Fresh medium was then added containing different drugs and the cells were incubated for $24 \mathrm{~h}$. $\left[{ }^{3} \mathrm{H}\right]$ Thymidine $(1 \mu \mathrm{Ci} /$ well, specific activity $25 \mathrm{Ci} / \mathrm{mmol}$, Amersham Pharmacia Biotech, UK) was added during the final $2 \mathrm{~h}$ of incubation (Ernst et al. 1989). After washing with DMEM, cells were incubated for $60 \mathrm{~min}$ with 5\% cold trichloroacetic acid (SigmaAldrich) and harvested. Radioactivity was measured using a liquid scintillation counter (Wallac, Turku, Finland).

\section{Biochemical determinations}

Alkaline phosphatase The ALP activity was assessed by measuring the release of p-nitrophenol at $37^{\circ} \mathrm{C}$ in $1 \mathrm{~h}$ when p-nitrophenylphosphate was used as a substrate (Sigma-Aldrich) (Farley \& Jorch 1983). The enzymatic reaction was stopped with $50 \mathrm{mM} \mathrm{NaOH}$ and absorbance measured at $\mathrm{A}_{405}$ using an ELISA plate reader (SLT Lab Instruments, Hillsborough, NC, USA). The results were expressed as $\mathrm{nmol} / \mathrm{min} / \mu \mathrm{g}$ protein.

Osteocalcin production Quantitative determination of osteocalcin (OC) levels was performed after $48 \mathrm{~h}$ incubation using a rat osteocalcin EIA kit from Biomedical Technologies, Inc. (Stoughton, MA, USA). The interand intra-assay coefficients of variation were $7 \%$ and $4 \%$ respectively and the sensitivity of the assay was $0.5 \mathrm{ng} / \mathrm{ml}$. Values were expressed as $\mathrm{ng} / \mathrm{mg}$ protein.

Proteins The total protein content was measured on sonicated pelleted cells with the Bio-Rad Protein Assay kit (Bio-Rad Laboratories, Richmond, CA, USA).

\section{Total RNA isolation and RT-PCR assay}

Total RNA was extracted from primary osteoblastic cells $\left(2 \times 10^{6}\right.$ cells/plate $)$ according to the single-step, acid guanidinium thiocyanate-phenol-chloroform extraction method (Chomczynsky \& Sacchi 1987). The integrity of extracted RNA was ascertained by electrophoresis on agarose gel. Two hundred and fifty nanograms total RNA from each sample were subjected to reverse transcription with Moloney murine leukaemia virus reverse transcriptase (InVitrogen, Carlsbad, CA, USA) followed by amplification using specific primers based on the published sequence of rat GHS receptor (forward primer: AGC GCTACTTCGCCATC; reverse primer: CCGATGAG ACTGTAGAG). PCR analysis of total RNA yielded a DNA fragment of the expected length for the specific mRNA. To normalize results for differences in RNA sampling, an aliquot of the same $\mathrm{RT}$ reaction was used to amplify a rat glyceraldehyde-6-phosphate (GAPDH) 



HEXARELIN

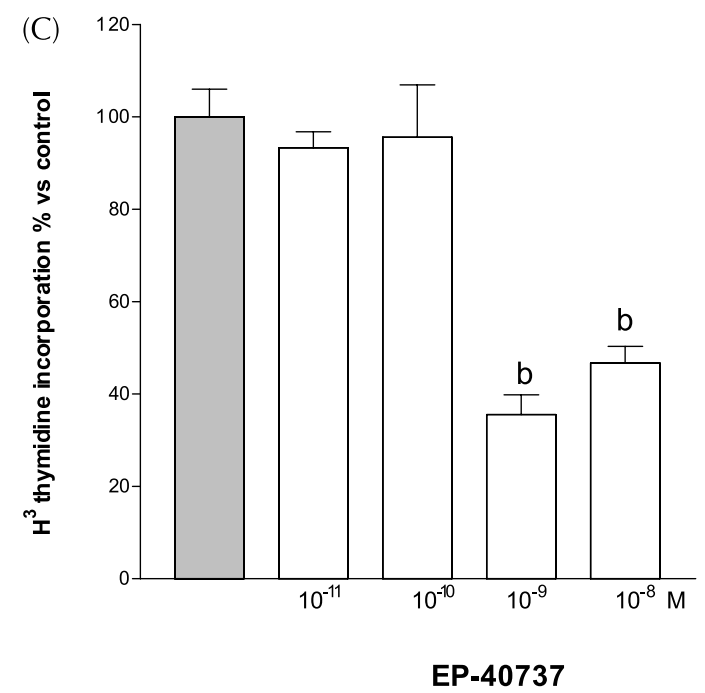

598-bp fragment. To ensure that PCR was performed in the linear amplification range, samples were initially analysed after $15,17,20,25,27,30,35$, and 40 cycles (data not shown). For each factor, we chose the cycle number that gave half of the maximal amplification.

\section{Western blotting}

Cells were lysed in RIPA buffer $(50 \mathrm{mM}$ Tris- $\mathrm{HCl}$ $\mathrm{pH} 7 \cdot 2,0 \cdot 1 \%$ SDS, $1 \%$ Nonidet P-40, $150 \mathrm{mM} \mathrm{NaCl}$ and $1 \%$ deoxycholic acid) containing protease inhibitor cocktail (Complete, Roche), homogenized by sonication (three 15 -s bursts) and centrifuged at $18400 \times \boldsymbol{g}$ for $5 \mathrm{~min}$, after $20 \mathrm{~min}$ on ice. The protein concentration of the supernatants was determined by BCA protein assay (Pierce Biotechnology, Rockford, IL, USA). Equal amounts of each sample ( $30 \mu \mathrm{g}$ or $60 \mu \mathrm{g})$ were separated by $10 \%$ SDS-PAGE and transferred to nitrocellulose membranes (Amersham). After blocking in 5\% non-fat milk in phosphate-buffered saline (PBS) containing $0 \cdot 2 \%$ Tween 20 , blots were incubated with antibody anti-GHS-R (GHSR11-S, Alpha Diagnostic, S. Antonio, TX, USA) 1:1000, followed by reaction with secondary anti-rabbit horseradish peroxidase (HRP)-conjugate and ECL detection (Pierce Supersignal, Pierce).

\section{Drugs}

Hexarelin (HEXA), EP-40737 (D-Thr-D-Trp(2-Me)Ala-Trp-D-Phe-Lys- $\mathrm{NH}_{2}$ ) and ghrelin were a kind gift from Dr Romano Deghenghi (Europeptides, Argenteuil, France), and have been prepared by conventional solidphase synthesis and purified to at least $98 \%$ purity by high-performance liquid chromatography by Neosystem (Strasbourg, France).

\section{Statistical analysis}

Statistical analysis was performed with a statistics package (PRISM, GraphPad Software, San Diego, CA, USA). All data are represented as the mean \pm S.E.M. Differences between groups were assessed by one-way analysis of variance (ANOVA) followed by Dunnett's $t$-test, with a probability of $P<0 \cdot 05$ considered statistically significant.

\section{Results}

\section{Osteoblast proliferation}

The viability of cells and the correct setting of culture conditions were tested by stimulating cell proliferation

Figure 1 Effect of different concentrations of ghrelin (A), hexarelin (B) and EP-40737 (C) on cultured rat osteoblasts proliferation. Data are expressed as a percentage of $\left[{ }^{3} \mathrm{H}\right]$ thymidine incorporated into nonactively growing fetal rat osteoblasts at $24 \mathrm{~h}$ (controls, shaded bars). Means \pm S.E.M. of 3-9 samples from the same cell population are reported. ${ }^{\mathrm{a}} P<0 \cdot 05,{ }^{\mathrm{b}} P<0 \cdot 01$ vs controls. 

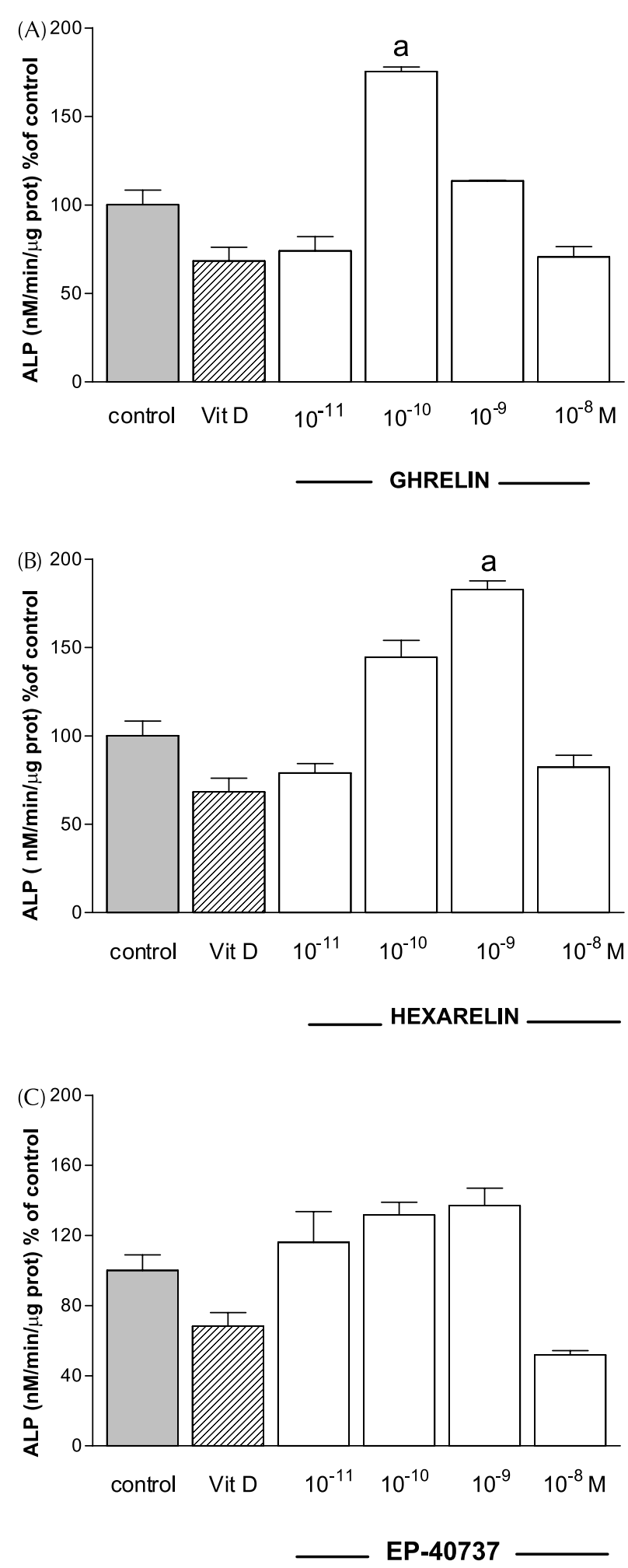

Journal of Endocrinology (2005) 184, 249-256 with DMEM containing 10\% FCS. In these wells, $\left[{ }^{3} \mathrm{H}\right]$ thymidine incorporation was significantly increased up to $300 \%$ over that of controls (data not shown).

Figure 1 shows the effect of ghrelin, HEXA and EP-40737 on osteoblast proliferation. At a concentration of $10^{-10} \mathrm{M}$, both ghrelin and HEXA induced a significant stimulation of osteoblast proliferation, that reached an increase of $33 \%$ and $21 \%$ respectively over controls $(P<0 \cdot 05)$. The stimulation of proliferation did not increase further when the concentration of the peptides was elevated to $10^{-9} \mathrm{M}$ (Fig. 1A,B).

Surprisingly, EP-40737 showed an antiproliferative effect in calvarial osteoblasts. In fact, when the cells were incubated with $10^{-8}$ and $10^{-9} \mathrm{M} \mathrm{EP}-40737$ the incorporation of $\left[{ }^{3} \mathrm{H}\right]$ thymidine decreased significantly to approximately $40 \%$ of that measured in controls $(P<0 \cdot 05$; Fig. 1C).

\section{Alkaline phosphatase activity and osteocalcin production}

To ascertain whether ghrelin and synthetic GHS are capable of affecting osteoblastic cell differentiation, we measured the changes in ALP activity and OC production in vitro.

As shown in Fig. 2, ghrelin increased ALP activity in osteoblasts with a typical bell-shaped curve, and the maximal effect was reached when cells were incubated with $10^{-10} \mathrm{M}$ ghrelin $(P<0 \cdot 05$ vs controls, Fig. $2 \mathrm{~A})$. A similar curve was seen after addition of HEXA to cultured osteoblasts. In this case, however, the maximal stimulatory effect on ALP was reached at $10^{-9} \mathrm{M}$ HEXA $(P<0 \cdot 05$ vs controls, Fig. 2B). At variance with these peptides, the stimulation of ALP activity by EP-40737 was less marked and never reached statistical significance (Fig. 2C).

Responsiveness of the cells was confirmed by the addition of $10^{-9} \mathrm{M}$ Vit $\mathrm{D}$; in our setting this concentration significantly decreased $(P<0 \cdot 05)$ ALP specific activity to $65 \%$ of controls.

Figure 3 shows the results obtained by measuring OC production from cultured osteoblasts. As expected, Vit D at $10^{-9} \mathrm{M}$ induced a significant increase of OC secretion. Both ghrelin and HEXA induced a consistent rise in OC secretion into the medium, although at different concentrations (Fig. 3A,B). A bell-shaped curve was obtained as a result of cell incubation with ghrelin, and the highest effect was obtained when the peptide was used at the concentration of $10^{-9} \mathrm{M}$. In contrast, HEXA was maximally effective at the lowest concentration tested $\left(10^{-11} \mathrm{M}\right)$.

Figure 2 Effect of different concentrations of ghrelin (A), hexarelin (B) and EP-40737 (C) on alkaline phosphatase (ALP) production in primary cultures of rat osteoblasts. Responsiveness of the cells was confirmed by the addition of $10^{-9} \mathrm{M}$ Vit D. Data are expressed as a percentage of controls. Means+s.E.M. of 3-9 replicates are reported. ${ }^{a} P<0 \cdot 05$ vs controls. 

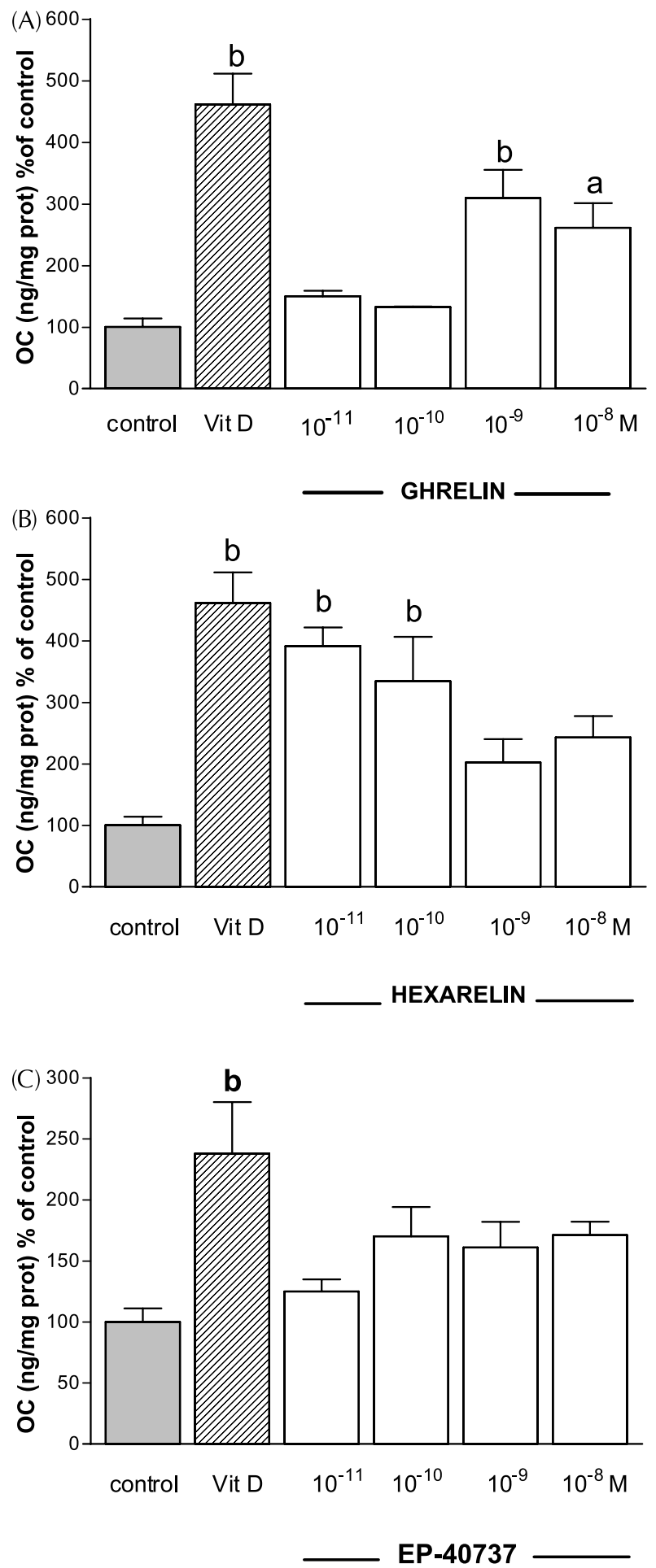

Figure 3 Effect of different concentrations of ghrelin (A), hexarelin (B) and EP-40737 (C) on osteocalcin (OC) production in primary cultures of rat osteoblasts. Vit D $\left(10^{-9} \mathrm{M}\right)$ was added as a control. Data are expressed as a percentage of controls. Means \pm S.E.M. of 3-9 replicates are reported. ${ }^{a} P<0 \cdot 05,{ }^{b} P<0 \cdot 01$ vs controls.
Also in this instance, EP-40737 did not share the effects of the other GHS and did not significantly stimulate OC production from cultured osteoblasts (Fig. 3C).

\section{GHS receptor expression in osteoblasts}

The expression of specific mRNA for GHS receptor in fetal calvaria cells was investigated by using a standard RT-PCR. Amplification of GHS receptor mRNA gave rise to a sharp band of the expected length of $288 \mathrm{bp}$ in calvaria cells harvested from passages 1 to 10 (Fig. 4). The effective translation of mRNA into the corresponding protein was demonstrated by Western blot from passages 5 to 10 (Fig. 5). In fact, a specific band of $44 \mathrm{kDa}$ corresponding to the molecular weight demonstrated for the GHS receptor was present in all samples. Interestingly, at passage 10 , a second band was strongly and specifically recognized by the anti-GHS receptor antibody, but its nature remains unknown (Fig. 5).

\section{Discussion}

Results of the present research are the first direct demonstration that rat calvarial osteoblasts express GHS-R1a receptors, considered the functional receptor for natural and synthetic GHS. The receptor has been detected by RT-PCR and by Western blot from the 1st to the 10th passage of osteoblasts. Furthermore, the present results demonstrate that ghrelin and HEXA stimulate osteoblast replication and increase ALP and OC production.

Previous reports have shown that both ghrelin and HEXA recognize with the same affinity the functional GHS-R1a receptor and that activation of this receptor stimulated an increase in $\left[\mathrm{Ca}^{2+}\right]_{\mathrm{i}}$ (intracellular calcium) and in $\mathrm{IP}_{3}$ generation (Root \& Root 2002). The effects of GHS on these second messengers correlate with their stimulatory effects on osteoblast proliferation since stimulation of the $\mathrm{PI} /\left[\mathrm{Ca}^{2+}\right]_{\mathrm{i}}$ signal pathways are generally associated with increased DNA and collagen synthesis (Yamaguchi et al. 1988).

One intriguing finding is that ghrelin and HEXA stimulated osteoblast proliferation in a fashion that was not directly dose-dependent. In fact, the maximal stimulatory activity of ghrelin and HEXA was observed at a low concentration $\left(10^{-10} \mathrm{M}\right)$ but not at higher concentrations $\left(10^{-8}\right.$ and $\left.10^{-9} \mathrm{M}\right)$. It could be speculated that by increasing the dose, the peptides could recognize different receptor subtypes having inhibitory proliferative activity thus tempering the stimulatory action prevailing at low concentrations. Supporting this view are the results obtained with EP-40737, showing that the peptide exerts an inhibitory activity on cell proliferation when added at high concentrations. In this context it is worth noting that different binding affinities have been shown for ghrelin and HEXA on GHS-1a receptor (Guerlavais et al. 2003,) 


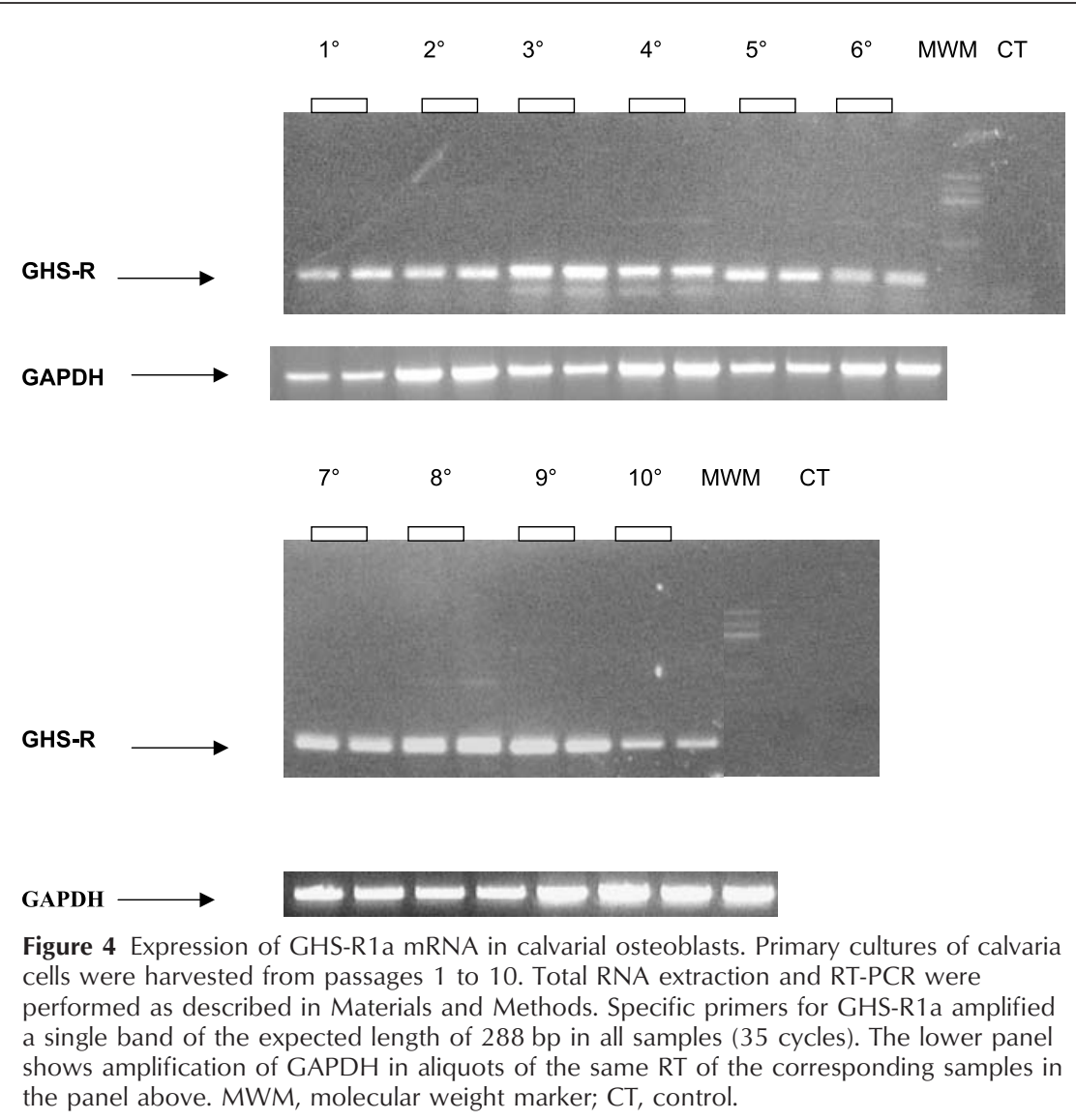

and that either stimulatory (Pettersson et al. 2002, Jeffery et al. 2003) or inhibitory (Ghè et al. 2002) effects on cell proliferation have been reported for these peptides.

The fact that EP-40737 behaves differently from these peptides could be related to the ability of the compound to recognize only the receptor subtype involved in antiproliferative activity. Accordingly EP-40737 does not share all the biological activities of ghrelin and HEXA (Torsello et al. 1998, 2000).

In agreement with the different effects of the three GHS on osteoblast proliferation, EP-40737 does not modify the biochemical markers of osteoblast differentia-

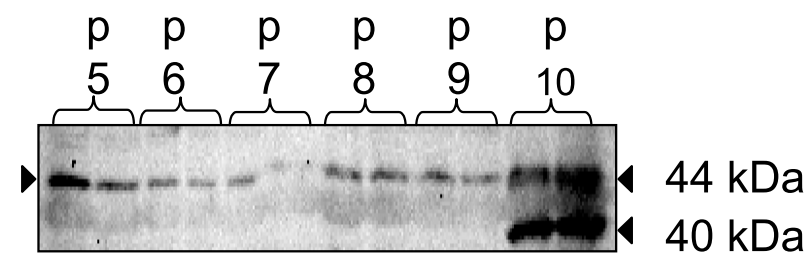

Figure 5 Characterization of GHS receptor protein expression in calvaria cells. The cellular receptor expression was determined by Western blot as described in Materials and Methods. Calvaria cells were harvested from passages (p) 5 to 10 . The $44 \mathrm{kDa}$ band corresponds to the GHS receptor. A representative Western blot is shown. tion, whereas ghrelin and HEXA significantly stimulate ALP activity and OC production. It would appear, therefore, that both the synthetic HEXA and the alleged natural ligand of the GHS receptors, ghrelin, modulate osteoblast differentiation. It has been reported that different signalling molecules are responsible for the regulation of osteoblast differentiation (Hakeda et al. 1987, Boguslawski et al. 2000) and it is known that ALP and OC production reflect different aspects of osteoblast differentiation and function. Thus it is likely that, by binding the GHS-R1a, ghrelin and HEXA could activate multiple signalling pathways that regulate, with different sensitivity, the osteoblastic functional activity. However, further investigations will be required to establish the mechanisms of GHS actions on osteoblast function and second messenger generation.

In line with this view, HEXA administered in vivo completely prevented the early decrease in serum ALP concentrations in gonadectomized rats, as a likely consequence of the direct activation of this enzyme in osteoblasts.

What would be the significance of these findings and what would happen in physiological conditions? The most likely agonist candidate for the GHS receptors on osteoblasts would be ghrelin. It has been known for a long 
time that gastrectomy causes osteopaenia in experimental animals (Bussabergher et al. 1938, Ivy 1940, Rümenappf et al. 1997). Although a deficiency in calcium may contribute, it is unlikely that gastrectomy-evoked osteopaenia simply reflects calcium deficiency, since supplementation with $\mathrm{CaCl}_{2}$ did not prevent the bone loss (Klinge et al. 1995, Rümenappf et al. 1997). The results support the view that the stomach is important for bone metabolism through mechanisms other than the regulation of intestinal calcium absorption. Interestingly enough, Lehto-Axtelius et al. (1998) demonstrated that the acidproducing (oxyntic) mucosa, which produces the most ghrelin, is the most important for bone metabolism. In view of these findings, we can suggest that ghrelin secreted from the stomach is conveyed through the circulation to its receptors located on bone.

An alternative hypothesis would be that the same bone cells are the source of ghrelin that would exert its effect through paracrine or autocrine mechanisms in a similar way as other local factors (cytokines, growth factors, prostaglandins, nitric oxide) (Canalis 1996). This view is supported by the single abstract report by Komatsu et al. (2000) who detected the ghrelin gene transcript in several different regions of mouse bone, including vertebrae, tibia, sternum and primary osteoblasts from calvaria.

At variance with our data, Sun et al. (2003) reported no role for ghrelin in the maintenance of bone density since ghrelin-null mice had normal bone mineral density and bone mineral content. Interestingly enough, food intake, body composition and reproductive function in these mice also did not differ from the wild-type littermates.

In view of the important regulatory role of ghrelin demonstrated for all these functions (van der Lely et al. 2004) it is likely that ghrelin-null mice would develop some compensatory mechanisms to overcome the lack of the peptide. However, it should be emphasised that evaluation of bone mineral density does not provide any information on osteoblast activity. In fact, the biochemical markers of osteoblast function, osteocalcin and ALP, were not determined in the ghrelin-null mice. Therefore, the possible physiological role of ghrelin in the control of osteoblast function cannot be ruled out and deserves further in vivo studies.

\section{Acknowledgements}

This work was supported, in part, by Centro di Ricerca per lo Studio delle Malattie Metaboliche Ossee e dell'Osteoporosi of the University of Brescia. The authors declare that there is no conflict of interest that would prejudice the impartiality of this scientific work.

\section{References}

Bellows CG, Aubin JE \& Heersche MN 1987 Physiological concentrations of glucocorticoids stimulate formation of bone nodules from isolated rat calvaria cells in vitro. Endocrinology 121 1985-1992.

Bodart V, Bouchard JF, McNicoll N, Erscher E, Carriere P, Ghigo E, Sejlitz T, Sirois MG, Lamontagne D \& Ong H 1999 Identification and characterization of a new growth hormone-releasing peptide receptor in the heart. Circulation Research 85 796-802.

Boguslawski G, Hale LV, Yu XP, Miles RR, Onyia JE, Santerre RF \& Chandrasekhar S 2000 Activation of osteocalcin transcription involves interaction of protein kinase A- and protein kinase C-dependent pathways. Journal of Biological Chemistry 275 999-1006.

Broglio F, Arvat E, Benso A, Papotti M, Muccioli G, Deghenghi R \& Ghigo E 2002 Ghrelin endocrine and non-endocrine actions. Journal of Pediatric Endocrinology and Metabolism 15 (Suppl 5) 1219-1227.

Bussabergher RA, Freeman S \& Ivy AC 1938 The experimental production of severe homogenous osteoporosis by gastrectomy in puppies. American Journal of Physiology 121 137-148.

Canalis E 1996 Mechanism of glucocorticoid action in bone: implication for glucocorticoid-induced osteoporosis. Journal of Clinical Endocrinology and Metabolism 81 3441-3447.

Chomczynsky P \& Sacchi N 1987 Single-step method of RNA isolation by acid guanidinium thiocynate-phenol-chloroform extraction. Analytical Biochemistry 162 156-159.

Ernst M, Heath JK \& Rodan GA 1989 Estradiol effects on proliferation, on messenger ribonucleic acid for collagen and insulin-like growth factor I, and parathyroid hormone-stimulated adenylate cyclase activity in osteoblastic cells from calvariae and long bones. Endocrinology 125 825-833.

Farley JR \& Jorch UM 1983 Differential effects of phospholipids on skeletal alkaline phosphatase activity in extracts in situ and in circulation. Archives of Biochemistry and Biophysics 221 477-488.

Ghè C, Cassoni P, Catapano F, Marrocco T, Deghenghi R, Ghigo E, Muccioli G \& Papotti M 2002 The antiproliferative effect of synthetic peptidyl GH secretagogues in human CALU-1 lung carcinoma cells. Endocrinology 143 484-491.

Guanapavan S, Kola B, Bustin A, Morris DG, McGee P, Fairclough P, Bhattacharya S, Carpenter R, Grossman AB \& Korbonitis M 2002 The tissue distribution of the mRNA of ghrelin and subtypes of its receptor, GHS-R, in humans. Journal of Clinical Endocrinology and Metabolism 87 2988-2991.

Guerlavais V, Boegli ND, Mousseaux CO, Heitz A, Deghenghi R, Locatelli V, Torsello A, Ghè C, Catapano F, Muccioli G, Galleyrand JC, Fehrentz JA \& Martinez J 2003 New active series of growth hormone secretagogues. Journal of Medicinal Chemistry 46 1191-1203.

Hakeda Y, Hotta T, Kurihara N, Ikeda E, Maeda N, Yagyu Y \& Kumegawa M 1987 Prostaglandin $E_{1}$ and $F_{2 \alpha}$ stimulate differentiation and proliferation, respectively, of clonal osteoblastic MC3T3-E1 cells by different second messengers in vitro. Endocrinology 121 1966-1974.

Inui A 2001 Ghrelin - an orexigenic and somatotrophic signal from the stomach. Nature Reviews/Neuroscience 2 1-7.

Ivy AC 1940 The effect of gastrectomy in animals. American Journal of Digestive Diseases 7 500-502.

Jeffery PL, Herington AC \& Chopin LK 2003 The potential autocrine/paracrine roles of ghrelin and its receptor in hormone-dependent cancer. Cytokine and Growth Factor Review 14 113-122.

Klinge B, Lehto-Axtelius D, Akerman M \& Hakanson R 1995 Structure of calvaria after gastrectomy. An experimental study. Scandinavian Journal of Gastroenterology 30 952-957.

Kojima M, Hosoda H, Date Y, Nakazato M, Matsuo H \& Kangawa K 1999 Ghrelin is a growth hormone-releasing acylated peptide from stomach. Nature 402 656-660.

Kojima M, Hosoda H, Matsuo H \& Hangawa K 2001 Ghrelin discovery of the natural endogenous ligand for the growth hormone secretagogue receptor. Trends in Endocrinology and Metabolism 12 $118-122$. 
Komatsu Y, Yasoda A, Sakuma Y, Miura A, Tanaka K, Hosoda H, Kojima M, Kangawa K, Hosoda K \& Nakao K 2000 Expression of the novel hormone releasing peptide, ghrelin in the osteoblastic cells. 82nd Meeting of The Endocrine Society, Toronto, Canada, p 259.

Lehto-Axtelius D, Stemstöm M \& Johnell O 1998 Osteopenia after gastrectomy, fundectomy or antrectomy: an experimental study in the rat. Regulatory Peptides 78 41-50.

van der Lely AJ, Tschop M, Heiman ML \& Ghigo E 2004 Biological, physiological, pathophysiological, and pharmacological aspects of ghrelin. Endocrine Reviews 25 426-457.

Locatelli V \& Torsello A 1997 Growth hormone secretagogues focus on the growth hormone-releasing peptides. Pharmacological Research 36 415-423.

Locatelli V, Rossoni G, Schweiger F, Torsello A, De Gennaro Colonna V, Bernareggi M, Deghenghi R, Muller EE \& Berti F 1999 Growth hormone-independent cardioprotective effects of hexarelin in the rat. Endocrinology 140 4024-4031.

Petersenn S 2002 Structure and regulation of the growth hormone secretagogue receptor. Minerva Endocrinologica 27 243-256.

Pettersson I, Muccioli G, Granata R, Deghenghi R, Ghigo E, Ohlsson C \& Isgaard J 2002 Natural (ghrelin) and synthetic (hexarelin) GH secretagogues stimulate H9c2 cardiomiocyte cell proliferation. Journal of Endocrinology 175 201-209.

Root AW \& Root MJ 2002 Clinical pharmacology of growth hormone and its secretagogues. Current Drug Targets. Immune, Endocrine and Metabolic Disorders 2 27-52.

Rümenappf G, Schwille PO, Erben RG, Schreiber M, Freis W, Schmiedl A \& Hohenberger W 1997 Osteopenia following total gastrectomy in the rat. State of mineral metabolism and bone histomorphometry. European Surgical Research 29 209-221.

Sibilia V, Cocchi D, Pagani F, Lattuada N, Moro GL, Pecile A, Rubinacci AM, Muller EE \& Netti C 1999 Hexarelin, a growth hormone-releasing peptide, counteracts bone loss in gonadectomized male rats. Growth Hormone and IGF Research 9 219-227.

Sibilia V, Pagani F, Guidobono F, Locatelli V, Torsello A, Deghenghi R \& Netti C 2002 Evidence for a central inhibitory role of growth hormone secretagogues and ghrelin on gastric acid secretion in conscious rats. Neuroendocrinology 75 92-97.

Sun Y, Ahmed S \& Smith RG 2003 Deletion of ghrelin impairs neither growth nor appetite. Molecular and Cellular Biology 23 7973-7981.

Svensson J, Lall S, Dickson SL, Bengtsson BA, Romer J, Ahnfelt-Ronne Ohlsson C \& Jansson JO 2001 Effect of growth hormone and its secretagogues on bone. Endocrine 14 63-66.

Torsello A, Luoni M, Schweiger F, Grilli R, Guidi M, Bresciani E, Deghenghi R, Muller EE \& Locatelli V 1998 Novel hexarelin analogs stimulate feeding in the rat through a mechanism not involving growth hormone release. European Journal of Pharmacology $360123-129$

Torsello A, Locatelli V, Melis MR, Succu S, Spano MS, Deghenghi R, Muller EE \& Argiolas A 2000 Orexigenics effects of hexarelin and its analogs in the rat hypothalamus. Indication for multiple growth hormone secretagogue receptor subtypes. Neuroendocrinology 72 327-332.

Yamaguchi DT, Hahn TJ, Beeker TG, Kleeman CR \& Muallem S 1988 Relationship of cAMP and calcium messenger systems in prostaglandin-stimulated VMR 106 cells. Journal of Biological Chemistry 263 10745-10753.

Received 31 May 2004

Accepted 29 September 2004 